\title{
Determinants of Capital Adequacy Ratio of Deposit Money Banks in Nigeria
}

Gabriel O Abba*, Ene Okwa, Benedict Soje and Lilian N Aikpitanyi

Department of Accounting, Federal University Wukari, Wukari, Nigeria

\begin{abstract}
Capital Adequacy Ratio (CAR) is an important measure of "safety and soundness" for banks and depository institutions because it serves as a buffer or cushion for absorbing losses. It is one of the major benchmarks for financial institutions the world over, especially with the introduction and adoption of the various Basel Accords. This study is an attempt to analyze the bank-specific determinants of CAR in the Nigerian Deposit Money Banks (DMBs) using balanced panel data collected from financial statements of 12 selected quoted banks for the ten-year period 2005-2014. The index for profitability which is ROA was found to be the most important determinant of CAR, having recorded the highest coefficient in the multiple regression result. The study found out that Capital Adequacy Ratio of Nigerian deposit money banks is well above the regulatory minimum set by CBN as well as the requirements of Basel Accord. Also, Nigerian banks' risk portfolio is quite high and ROA is quite low. Depositors' interests are well protected as the asset base of DMBs is well above the total deposits. The study concludes that CAR is largely determined by banks risk-portfolio, deposit level, profitability and asset quality and that CAR of Nigerian banks is well above the regulatory minimum. The study recommends that Nigerian deposit money banks should adopt a more pragmatic risk-management mechanism and a risk-based capital maintenance approach backed by a robust data management system. The study recommends improvement in operational performance of banks, strict compliance with various capital regulations, frequent stress tests for banks and more detailed disclosure practice to include details of changes in Tier I and Tier II capital, risk-weighted assets and trend analysis of changes in Capital Adequacy Ratio.
\end{abstract}

Keywords: Capital Adequacy Ratio (CAR); Return on Assets (ROA); Banking risks and asset quality

\section{Introduction}

Capital Adequacy Ratio (CAR) is one of the fundamental measures of the strength and wellness of banks the world over. Abba et al. [1] studied the relationship between Capital Adequacy Ratio and banking risks in Nigeria and observed that Capital Adequacy ratio is an important measure of "safety and soundness" for banks and depository institutions because it serves as a buffer or cushion for absorbing losses. Capital adequacy is the first letter ' $\mathrm{C}$ ', in the popular acronym 'CAMELS' in banking parlance. The importance of the concept has drawn the attention of financial experts and policy makers both locally and internationally, especially Central Banks, Federal Reserves, Deposit money banks, Insurance Companies and the World Bank and has led to the popular Basel Accords. The Basel Accord recommends minimum Capital Adequacy Ratios that banks should meet so as to safeguard depositors' interest and ensure continued existence of banks. Thus, the Basel Accords is the global response to the fragility and incessant crisis that characterised the banking world in the 1970's and 1980's. The Basel Committee on Banking Supervision handed down the first Basel Accord in 1988 which is the popularly referred to as Basel I. This marked a significant milestone in the governance of the global financial system as it focused on defining regulatory capital, measuring risk-weighted assets, and setting minimum acceptable levels for regulatory capital [2]. Thus applying the Basel Capital Adequacy Ratio Standards serves to promote the stability and efficiency of the financial system by reducing the likelihood of banks becoming insolvent. So far there have been Basel I, Basel II and Basel III. Basel I and Basel II fixes minimum Capital Adequacy Ratio at $8 \%$ while in 2010, the world's central bankers, represented collectively by the Bank of International Settlements (BIS) handed down Basel III which hiked Capital Adequacy Ratio requirement from $8 \%$ to at least $10.5 \%$ of a bank's risk-weighted assets [3].

Lindgren et al. [4] observed that since 1980, over 130 countries, comprising almost three fourths of the International Monetary Fund's member countries, have experienced significant banking sector problems, with 41 instances of crisis in 36 countries and 108 instances of significant problems. This situation posed serious concern for the policy makers and regulators. In the aftermath of the financial crisis, there have been efforts by regulatory authorities to make banks stronger. To accomplish this, governments across the developed and developing worlds are compelling banks to raise fresh capital and strengthen their balance sheets, and if banks cannot raise more capital, they are told to shrink the amount of risk assets (loans) on their books.

In Nigeria, the Central Bank being the apex regulator of the banking industry increased the minimum capital base for commercial banks to twenty-five billion naira in 2005 . This policy popularly referred to as the recapitalization or consolidation policy resulted in the reduction of Nigeria motley group of mainly anaemic eighty-nine banks to twentyfive bigger, stronger and more resilient financial institutions [5]. However, increasing the capital base of banks through recapitalization, may increase the Capital Adequacy Ratio in the short-run but may not necessarily increase it in the long-run as banks may increase their risk portfolio at the expense of their capital base as a result of increased liquidity and overall financial position. The aftermath of the international banking crisis and the negative trends in the currency and banking markets attracted the attention of scholars who investigated

*Corresponding author: Gabriel O Abba, Department of Accounting Federal University Wukari, Wukari, Nigeria, Tel: +234-8031580589; E-mail: angelgabrielabba@gmail.com

Received April 13, 2018; Accepted April 26, 2018; Published May 07, 2018

Citation: Abba GO, Okwa E, Soje B, Aikpitanyi LN (2018) Determinants of Capital Adequacy Ratio of Deposit Money Banks in Nigeria. J Account Mark 7: 271. doi: 10.4172/2168-9601.1000271

Copyright: @ 2018 Abba GO, et al. This is an open-access article distributed under the terms of the Creative Commons Attribution License, which permits unrestricted use, distribution, and reproduction in any medium, provided the original author and source are credited. 
the immediate and remote causes of the crisis and the behaviour of Capital Adequacy Ratio in relation to other banking indices. Some of these scholars include: Davidoff, Steven and Zaring [6], Coffee [7], Chorafas [8], Brewer et al. [9], Bordo [10], Bieri [11], Bayne [12], Atik [13], Williams [5], Al-Sabbagh [14], Al-Tamimi and Obeidat [15], Wong [16] and Abba et al. [1]. These various scholars raised a host of questions bothering on the linkages between Capital Adequacy Ratio and financial sector deregulation as well various micro and macro prudential issues such as risk level and risk behaviour of banks, asset quality, profitability, deposit level and macro-economic indicators including inflation rate, size and growth rate of the economy, money supply, lending rate, minimum wage and banking sector regulation. Since macro-economic variables are purely external factors to deposit money banks, this study focuses on behaviours of variables that are considered internal to the operations of the banks. Based on studies conducted in other developing economies, landmark policies of the apex bank, the Basel Capital Adequacy Ratio (CAR) computation model as well as the peculiarity of the Nigerian banking industry, certain variables have been selected and included in this study. These variables include risk portfolio of banks, level of deposits with banks, profitability and asset quality of banks.

Thus in the wake of rising level of non-performing loans, expansion of banking operations and the attendant rise in their risk portfolio with the adoption of Basel II and preparations for the adoption of Basel III by the Nigerian banking industry, there is a great need for an empirical study on the major determinants of Capital Adequacy Ratio, especially from the perspective of micro-prudential factors of deposit money banks in Nigeria.

\section{Statement of the problem}

Although Capital Adequacy Ratios at commercial banks have increased since the risk-based standards have been introduced, the question arose as to what degree of these increases were a response, specifically to risk-based capital maintenance, other bank specific ratios such as Deposit Asset Ratio, Asset Quality Ratio (AQR) as well as financial performances of banks in terms of profitability. Therefore this study employed multiple regression model to determine the extent to which changes in Capital Adequacy Ratio in the risk-based capital regime are primarily determine by key bank-specific ratios as contained in the Basel Accord model for capital adequacy computation as well as the Prudential Guideline of the Central Bank of Nigeria. Furthermore, the study is necessary in that there have not been sufficient researches on bank-specific determinants of Capital Adequacy Ratio since the wake of the banking sector consolidation in 2005 and the adoption of Basel II and III in Nigeria. Thus, this study is an attempt to fill the identified gaps and thus contribute to literature on the subject matter in Nigeria.

\section{Literature Review and Theoretical Framework}

\section{Capital adequacy ratio and risk-weighted asset ratio}

Abba et al. [1] examined the relationship between CAR and banking risks in the Nigerian deposit money banks and observed that the risk weighted asset ratio was higher than the CAR in the Nigerian banking industry. They further observed a negative relationship between Capital Adequacy Ratio and the risk portfolio of banks represented by the risk-weighted assets ratio. The findings of Abba et al. [1] were consistent with Al-Sabbagh and Magableh [14] whose study on the determinants of CAR in Jordanian banks produced similar result. Al-Tamini and Obeidat [15] also carried out a study on the determinants of CAR of commercial banks in Jordan and found out a negative but not significant relationship between credit risks and CAR. They observed negative significant relationship between CAR and interest rate risk. In the case of liquidity risk, there result shows a direct relationship between liquidity risk and CAR, thus contradicting the findings of Williams [5] and that of Berrospide and Edge [17]. However, the methodologies employed in these studies were not robust enough as only OLS was employed and none of the studies tested for heteroskedasticity.

Koehn and Santomero [18] examined a portfolio reaction to capital requirements by investigating the effect of capital ratio regulation on portfolio behaviour of commercial banks. They found that an increase in variance of returns increases the probability of failure, while an increase in returns or capital ratio decreases failure risk. Their findings are consistent with Madura and Zarruk [19].

\section{Capital adequacy ratio and deposit assets ratio}

One of the key functions of commercial banks is to accumulate funds in the form of deposits from the surplus sectors of the economy and make same available to the deficit sectors of the economy. Thus deposits constitute a significant proportion of banks total current liabilities and as such require maintenance of adequate capital by banks. Yu [20] defined adequate capital for banks as the level at which the deposit insuring agency would just break-even in guaranteeing the deposits of individual banks with the premium the bank pays. An option theoretical framework was employed in his study for measuring fair capital adequacy holdings for a sample of depository institutions in Taiwan, during 1985-1992. Sharpe [21] defined capital as a difference between assets and deposits, so the larger the ratio of capital to assets (or the ratio of capital to deposit) the safer the deposits. As capital was adequate, deposits were "safe enough". His idea was that if the value of an institution's assets may decline in the future, its' deposits will generally be safer, the larger the current value of assets in relation to the value of deposits.

Williams [5] in his study on the determinants of capital adequacy in the banking sub-sector of the Nigerian Economy observed that the deposit liabilities and liquidity risk variables are not correctly signed and are not statistically significant but may increase capital adequacy base via increase in money supply. Al-Shabbagh and Magableh [14] hypothesised a positive relationship between deposit to asset ratio and CAR and opined that when deposits increase, banks should be more regulated and controlled to guarantee the depositors rights, and to protect a bank from insolvency. He further observed that if depositors cannot assess financial soundness of their banks, banks will maintain lower than optimal capital ratios.

\section{Capital adequacy ratio and asset quality ratio}

The condition and quality of individual asset categories can trigger financial problems and act as an important accelerator of bank fragility. Blose [22] found that provision for loan losses caused a decline in CAR. Hassan and Bashir [23] and ChoI [24] also argued a negative relationship between CAR and AQR. Al-Sabbagh and Magableh [14] also hypothesised a negative and significant relationship between CAR and ratio of total loan loss provision to total loan. He argued that loan loss provision otherwise called Asset Quality Ratio is used in his model to determine the impact of new provisions for possible loan losses and loans written-off on bank's capital level. Banks with more loan loss reserves are more aggressive in their lending practices, and are willing to accept losses instead of negotiating concession with loan defaulters. 
In addition, a high loan loss reserves may signal banks that are willing to write-off problem loans which are expected to reduce bank credit risk. Thus he found out using multiple linear regressions that there exists a negative and significant relationship between CAR and asset quality which he called loan provision ratio (LPR). He observed like Blose [22], Hassan and Bashir [23] and ChoI [24] who found also the same negative relationship, that Jordanian Banks have increased their loan loss reserves accounts since 1995, to reduce their credit risks and maintain a higher CAR. Debarsh and Sukanya [25] emphasized that the reduction of non-performing asset is necessary to improve profitability of banks and comply with the capital adequacy norms as per the Basel Accord.

\section{Capital adequacy ratio and returns on assets}

Al-Sabbagh and Magableh [14] and Harold [26] hypothesised a significant positive relationship between profitability and CAR and gave the reason that banks as profit making organizations are interested in high returns for shareholders, and will optimize their capital levels to earn higher returns on their assets. Thus when Return on Assets increases, CAR should increase. Al-Sabbagh and Magableh [14] observed that the CAR had a high positive correlation (about +0.75 ) with Returns on Assets of Jordanian banks during the period of his study, which meant that as ROA increased, CAR also increased. His position was further corroborated by the coefficient of Returns on Assets (ROA) in his model which was positive and significant at $5 \%$. Al-Tamimi and Obeidat and Obeidat [15] analysed the determinants of CAR in Jordanian commercial banks and observed a strong direct and statistically significant relationship between ROA and capital adequacy among the study sample. Their finding is consistent with that of other previous studies such as Mekhlafi [27] and Makhamrerh [28].

Goddard et al. [29] supports the prior finding of positive relationship between capital/asset ratio and bank's earnings. A positive relation between CAR and profitability was further suggested by Kosmidou, [30], Demirguc-Kunt and Huizinga [31], Ben [32], Kosmidou et al. [33], Valverde and Fernandez [34] Brock and Suarez [35], Demirguç-Kunt et al. [36] and Saunders and Schumacher [37]. However, this position is different from that of Olaleka and Adeyinka [38] who observed and concluded that there is no significant relationship between capital adequacy and profitability in domestic banks in Nigeria.

\section{Theoretical Framework}

This study was guided by the economic efficiency theory of Odunga et al. [39]. The economic efficiency theory states that firms should achieve their output at the lowest possible cost per unit produced. According to this theory, optimal production can be achieved by economies of scale. Thus, in the short run, maximum operational efficiency is attained at the level of output at which all accessible economies of scale are taking advantage of such efficiency. In the long run, lifting the capacity of existing systems can increase the optimal level of productive efficiency $[40,41]$. Since the study is an attempt to explain the extent to which the four independent variables determine the dependent variable (CAR), underpinning the study with the economic efficiency theory is necessary.

\section{Methodology \\ Research design}

Correlational and descriptive research designs have been employed in the study using panel data for a period of ten years i.e., 2005-2014.

\section{Population and sampling}

The domain of the study is the banking industry out of which twelve banks have been selected.

\section{Sources of data}

The study used secondary data for the multiple regression analysis. As such the data for the study was gleaned purely from published financial statements of the sampled banks, thus making the data source completely secondary in nature.

\section{Techniques of data analysis}

The tool of data analysis for the research is the Panel Multiple Regression Model (PMRM). This tool is preferred for the analysis because the research is empirical in nature and the data for the study is a balance panel data. Specifically the methods of analysis employed in the study were Ordinary Least Square (OLS), Random Effects Model (REM) and Fixed Effects Model (FEM). OLS was used as a basis of comparison with previous empirical studies. However, using traditional Ordinary Least Square alone may produce spurious regression problem that can lead to statistical bias [42]. As such, REM and FEM have also been adopted after which Hausman's Specification test was carried out which suggested the adoption of REM rather than FEM for the study. However, the regression result for the REM was not materially different from the OLS result (Table 1).

\section{Model specification}

The following model has been proposed for the study:

$$
\mathrm{CAR}_{\mathrm{it}}=\beta_{0}+\beta_{1} \mathrm{RAR}_{\mathrm{it}}+\beta_{2} \mathrm{DAR}_{\mathrm{it}}+\beta_{3} \mathrm{AQR}_{\mathrm{it}}+\beta_{4} \mathrm{ROA}_{\mathrm{it}}+\varepsilon_{\mathrm{it}}
$$

Where $\mathrm{CAR}_{\mathrm{it:}}$ Capital Adequacy Ratio of bank i at a period t; $\mathrm{RAR}_{\mathrm{it}}$ : Risk-weighted Asset Ratio of bank i at a period t; $\mathrm{DAR}_{\mathrm{it}}$ : Deposit Asset Ratio of bank i at a period t; $\mathrm{AQR}_{\mathrm{it}}$ : Assets Quality Ratio of bank i at a period t; ROAit: Returns on Assets of bank i at a period $t ; \beta_{0}$ : Intercept; $\beta_{1-5}:$ Coefficient of the independent variables; $\varepsilon_{\mathrm{it}}$ : Residual or error term.

\section{Results and Discussions}

This section shows the results of the analysis carried out in this study, the interpretations as well as the discussion of major findings.

\section{Descriptive statistics}

A total of 120 observations were made for each of the study variables

\begin{tabular}{|l|l|}
\hline Variables & Measurement basis \\
\hline apital Adequacy Ratio (CAR) & $\begin{array}{l}\text { Total Qualifying Capital } \\
\text { Total Risk - weighted Asset } \\
\text { Total Qualifying Capital=1 }\end{array}$ \\
\hline Tier Capital
\end{tabular}

Table 1: Summary of variables measurement. 
over the ten years period of 2006-2015 (Table 2). Capital Adequacy Ratio for the sampled banks averaged $28 \%$ during the period of the study. This figure is high compared with the regulators requirement of $10 \%$ as enshrined in the Central Bank of Nigeria 2010 Prudential Guidelines for Deposit Money Banks. The deposit to asset ratio on the other hand is $72 \%$ with an average dispersion of $16.4 \%$ represented by the standard deviation. This means that depositors money are secured as only an average of $72 \%$ of banks total asset will be required to pay back depositors in the event of liquidation. ROA for the study period was $2 \%$ with a standard deviation of $1.2 \%$. Profitability is low in the Nigerian banking industry and the extent of dispersion from the average value of ROA as depicted by the standard deviation is high. The average value of AQR is $15 \%$ with a standard deviation of $9 \%$. This is rather high compared with the minimum ratio of $10 \%$ as enshrined in the Central Bank of Nigeria Prudential Guidelines 2010. Also, the dispersion from the average $\mathrm{AQR}$ by the observed data is high.

\section{Correlation matrix}

Checking the pattern of relationships between dependent and independent variables, it is observed that the variables correlate perfectly well (between -0.68 and 0.71 ) and all are significant at $1 \%$ (Table 3). Thus, there is no correlation coefficient particularly large (greater than 0.9) and there is no significant value less than 0.01 . On the other hand, the relationships between most of the explanatory variables are not very high, and as such are not significant drawback to the study. This would further be proven by the result of the autocorrelation diagnostic. Hence there is no problem of singularity of data.

\section{Hausman specification test}

To decide whether to adopt the FEM or REM, Hausman specification test was carried out to select the preferred model. It basically tests whether the unique errors (term error) are correlated with the regressors [23]. The result of the test reveals that the Ch2 value of 0.25 has a probability of 0.9928 and as such, it is not significant at the $5 \%$ level. As such, the result of the REM was adopted for the study. A comparison of the multiple regression results of the OLS model and REM in Tables 4 and 5 reveals that they are the same. Therefore the study adopted the result of the OLS.

\section{Presentation and analysis of regression results}

Three multiple regression analyses have been carried out using OLS, FEM and REM after which the Hausman Specification test was carried out. The summary of the three regression results obtained from the model of the study which was presented in Tables 4-6.

\begin{tabular}{|c|c|c|c|c|c|}
\hline Variables & Observations & Mean & Std. Dev. & Minimum & Maximum \\
\hline CAR & 120 & 0.28 & 0.076 & 0.10 & 0.49 \\
\hline RAR & 120 & 0.74 & 0.146 & 0.32 & 0.93 \\
\hline DAR & 120 & 0.72 & 0.164 & 0.26 & 0.90 \\
\hline ROA & 120 & 0.02 & 0.012 & 0.00 & 0.05 \\
\hline AQR & 120 & 0.15 & 0.090 & 0.02 & 0.36 \\
\hline
\end{tabular}

Table 2: Descriptive statistics of dependent and independent variables.

\begin{tabular}{|l|l|l|l|l|l|l|}
\hline Variables & Correlation & CAR & RAR & DAR & ROA & AQR \\
\hline CAR & Pearson correlation 1.000 & & & & \\
\hline RAR & Pearson correlation $0.713^{* *}$ & 1.000 & & & \\
\hline DAR & Pearson correlation $0.708^{* *}$ & $0.849^{* *}$ & 1.0000 & & \\
\hline ROA & Pearson correlation $0.543^{* *}$ & $0.512^{* *}$ & $0.566^{* *}$ & 1.000 & \\
\hline AQR & Pearson correlation & $-0.682^{* *}$ & $-0.746^{* *}$ & $-0.711^{* *}$ & $-0.533^{* *}$ & 1.000 \\
\hline
\end{tabular}

${ }^{* *}$ Correlation is significant at the 0.01 level (2-tailed)

Table 3: Correlation matrix of dependent and independent variables.

\begin{tabular}{|c|c|c|c|}
\hline Statistics variables & Beta coefficients & t-Values & Significance \\
\hline RAR & 0.1347 & 2.13 & 0.035 \\
\hline DAR & 0.1055 & 1.92 & 0.057 \\
\hline ROA & 0.9457 & 2.03 & 0.044 \\
\hline AQR & -0.2084 & -2.64 & 0.009 \\
\hline \multicolumn{3}{|c|}{} \\
\hline$R^{2}$ & 0.5956 \\
\hline Adjusted $R^{2}$ & 0.5816 \\
\hline F-statistic & \multicolumn{3}{|c}{0.35} \\
\hline Significance & 0.0000 \\
\hline
\end{tabular}

Table 4: Stata 11 regression results for Ordinary Least Square (OLS) model.

\begin{tabular}{|c|c|c|c|}
\hline Statistics variables & Beta coefficients & T-values & Significance \\
\hline RAR & 0.1347 & 2.13 & 0.033 \\
\hline DAR & 0.1055 & 1.92 & 0.054 \\
\hline ROA & 0.9457 & 2.03 & 0.042 \\
\hline AQR & -0.2084 & -2.64 & 0.008 \\
\hline \multicolumn{3}{|c|}{} \\
\hline$R^{2}$ Within & 0.6104 \\
\hline$R^{2}$ Between & 0.0241 \\
\hline$R^{2}$ Overall & 0.5956 \\
\hline Wald Ch2 & \multicolumn{3}{|c}{} \\
\hline Significance & & 0.0000 \\
\hline
\end{tabular}

Table 5: Stata 11 regression results for Random Effects Model (REM).

\begin{tabular}{|c|c|c|c|}
\hline Statistics variables & Beta coefficients & t-Values & Significance \\
\hline RAR & 0.1276 & 1.86 & 0.065 \\
\hline DAR & 0.1129 & 1.96 & 0.053 \\
\hline ROA & 0.9155 & 1.88 & 0.063 \\
\hline AQR & -.02127 & -2.52 & 0.013 \\
\hline$R^{2}$ within & & & \\
\hline $\mathrm{R}^{2}$ between & & 0.6104 \\
\hline $\mathrm{R}^{2}$ overall & & 0.0208 \\
\hline F-statistic & & 0.5955 \\
\hline Significance & & 40.74 \\
\hline
\end{tabular}

Table 6: Stata 11 regression results for Fixed Effects Model (FEM).

$$
\mathrm{CAR}_{\mathrm{it}}=\beta_{0}+\beta_{1} \mathrm{RAR}_{\mathrm{it}}+\beta_{1} \mathrm{DAR}_{\mathrm{it}}+\beta_{3} \mathrm{AQR}_{\mathrm{it}}+\beta_{4} \mathrm{ROA}_{\mathrm{it}}+\varepsilon_{\mathrm{it}}
$$

Since the Hausman specification test carried out reveals that the result of the REM, which is the same with the result of the OLS, should be adopted, the study therefore reverts to the OLS. As such, the ensuing interpretations are based on the results of the OLS models. The model is therefore estimated as follows:

$$
\mathrm{CAR}_{\mathrm{it}}=0.11+0.13 \mathrm{RAR}_{\mathrm{it}}+0.11 \mathrm{DAR}_{\mathrm{it}}+0.95 \mathrm{ROA}_{\mathrm{it}}-0.21 \mathrm{AQR}_{\mathrm{it}}
$$

Table 4 shows that all but one of the coefficients of the independent variables is positive. This corroborates the correlation matrix result which shows positive correlation between CAR and three independent variables (Risk-weighted Asset Ratio, Deposit Asset Ratio and ROA).

The regression result shows that $R^{2}$ is 0.60 . This signifies that $60 \%$ of total variation in CAR is caused by RAR, DAR, ROA and AQR. This indicates that the model is fit and the explanatory variables are properly selected, combined and used [23]. The Adjusted $\mathrm{R}^{2}$ for the model is $58 \%$. Since the adjusted $\mathrm{R}^{2}$ is very close to the coefficient of determination, this further proves that the mode is fit and the explanatory variables are properly selected, combined and used.

\section{Discussion of findings}

Capital adequacy ratio and banking risks: As shown in the result 
of the test of the first hypotheses for the study, a positive and significant relationship was observed between CAR and risk-weighted assets ratio. It is widely recognized that capital can serve as a buffer to absorb these unexpected losses, reduce the probability of insolvency and, therefore, the expected bankruptcy cost [43].

A possible explanation for this result is the fact that banks are risk-averse and would always design investment strategies that would preserve capital and cushion the effect of rising risk level. They are well aware that increasing risk level raises their risk of business failure. They are also aware that there is a limit to the risk level their current capital base can absorb. As such, in order to take-in more risks, banks tend to increase their capital base. On the other hand, where there is a reduction in capital as a result of losses, this tends to affect their future capacity to take-in more risks. This result is consistent with Al-Tamimi et al. [15], Bokhari et al. [44], Choi [24], Renolds et al., [45], Markus [46], Shome et al., [47] and Williams [5]. Notable exceptions have been observed in similar studies carried out by Abba et al. [1], Al-Sabbagh and Magableh [14], Khrawash et al. [48], Berrospide and Edge [17], Madura and Zarruk [19], Koehn and Santomero [18], Karles et al. [49] and Mpuga [50].

Capital adequacy ratio and bank deposits: As expected, the regression results reveal positive and significant relationship between CAR and Deposit to Assets Ratio. Some researchers in consonance with the result of this study also observed positive and significant relationship between CAR and Deposit to Assets Ratio. Al-Sabbagh and Magableh [14], who empirically examined the determinants of CAR in Jordanian Banks, observed in relation to DAR that the ratio is the most important variable on which the Basel Accord depends, to guarantee depositors' rights. He observed that after bank's regulations and the application of Basel's standards between 1995 and 2001, Capital Adequacy Ratio (CAR) was positively and significantly affected by size of banks' deposits. Williams [5], in line with Al-Sabbagh and Magableh [14] also observed that increase in deposit liabilities may increase CAR via increase in money supply. Bokhari and Ali [44] in line with Al-Sabbagh and Magableh [14] also observed that fund deposited by banks' customers is a major factor that contributes in determining their CAR. Deposits are cheap source of finance as compare to the external sources of finance, such as bonds, loans from business angels and through syndications [51].

Capital adequacy ratio and profitability: In consonance with the Basel model the result of the study reveals that Returns on Assets (ROA) which is the measure of profitability is significantly associated with the CAR of Nigerian deposit money banks at $5 \%$ level of significant. With an average ROA of about $2 \%$ from the twelve sampled banks, it can be deduced that assets of Nigerian banks yield positive returns which are not only healthy for the going-concern status of the banks, but also their capital adequacy position at any point in time.

Similar researches that support this finding include that of Staikouras and Wood [52] who claimed that there exists a positive link between a greater equity and profitability among EU banks. Abreu and Mendes [53] in line with the finding of this study also trace a positive impact of equity level on profitability. Goddard et al. [29] supports all these findings of positive relationship between capital/asset ratio and bank's earnings with similar conclusion in his study. Al-Sabbagh [14], Mekhlafi [27] and Makhamrerh [28] also observed that the CAR had a high positive correlation with ROA of banks during the period of their study. A positive relation between CAR and profitability was further suggested by Kosmidou [30]; Demirguc-Kunt and Huizinga [31]; Naceur [32], Pasiouras et al. [33], Valverde and Fernandez [34],
Brock and Suarez [35], Demirguç-Kunt et al. [36] and Saunders and Schumacher [37], Pasiouras and Kosmidou [54], Staikouras and Wood [52], Abreu and Mendes [53] and Goddard et al., [29]. However, Olaleka and Adeyinka [38] who conducted an empirical research on the relationship between CAR of banks and their profitability observed and concluded contrary to the finding of this study that there is no significant relationship between capital adequacy and profitability in domestic banks in Nigeria.

Capital adequacy ratio and asset quality ratio: The study reveals a significant negative relationship between CAR and asset quality in the Nigerian Deposit Money Banks. This result was expected. Asset quality being the only independent variable in the study with a negative coefficient represented by the beta value of AQR is -0.208 and the $\mathrm{t}$-value is -2.64 which are significant at $1 \%$, shows that for every unit increase in $\mathrm{AQR}, \mathrm{CAR}$ reduces by about $21 \%$.

The reason behind this is not far-fetched. Poor asset quality which is detected by high and increasing ratio of non-performing loans to total loans and poor results of age analysis of debtors tend to erode the quantity and quality of capital. In line with this position, some of the literatures reviewed revealed similar findings. Blose [22] found that provision for loan losses caused a decline in CAR. Hassan and Bashir [23] and ChoI [24] also argued a negative relationship between CAR and AQR. Furthermore, Al-Sabbagh and Magableh [14] hypothesised a negative and significant relationship between CAR and ratio of total loan loss provision to total loan. He argued that loan loss provision otherwise called Asset Quality Ratio is used in his model to determine the impact of new provisions for possible loan losses and loans writtenoff on bank's capital level. Overall he observed that there exists a negative and significant relationship between Capital Adequacy Ratio and asset quality which he called loan provision ratio (LPR). Debarsh and Sukanya [25] in consonance with the result of this study emphasized that the reduction of non-performing asset is necessary to improve profitability of banks and comply with the capital adequacy norms as per the Basel Accord.

\section{Conclusion and Recommendations}

The overall conclusion of the study is that Capital Adequacy Ratio is largely determined by banks risk-portfolio, deposit level, profitability and asset quality and that while risk level, deposits level and profitability are positively related to CAR, AQR is negatively related to Capital Adequacy Ratio.

The following recommendations are for deposit money banks:

a) Since the study reveals that profitability is the major and most important determinant of CAR and profitability is also a major variable in the Basel Accord capital adequacy computation model, Nigerian deposit money banks should increase their reserves accounts in order to enhance their capital adequacy position and the overall safety and soundness of the entire banking system through better operational results and more prudent management of their available resources.

b) Nigerian banks should adopt a risk-based approach in managing capital instead of the present practice of focusing on the paid-up capital and retained earnings only as there is significant relationship between CAR and banking risks.

c) Banks should also ensure strict compliance with regulatory requirements bothering on $\mathrm{CAR}, \mathrm{AQR}$, risk management and loans administration.

d) Based on the average RAR from the result of this study, 
CBN should take more decisive measures aimed at tightening the risk management framework of the Nigerian banking sector as this will have a positive effect on their Capital Adequacy Ratio and the overall safety and soundness of the banking sector.

e) Since deposit to asset ratio is positively related to Capital Adequacy Ratio, the apex regulatory financial institution should establish adequate capital limit for any given amount of deposits with banks at regular intervals, rather than maintaining a single rate for a long period of time. Thus, it should be that banks, who intend to increase their market share by attracting more depositors and deposits, should ensure that they attain the commensurate level of Capital Adequacy Ratio as stipulated by the apex bank.

\section{References}

1. Abba GO, Zachariah P, Inyang EE (2013) Capital Adequacy Ratio and banking risks in the Nigeria money deposit banks. Research Journal of Finance and Accounting 4: 17-25.

2. Blom J (2009) The regulation of global banking: Shifts in governance under the Basel Accords. New York: International Studies Association.

3. Hanke SH (2013) Basel's capital curse. Financial Nigeria: Development and Finance Journal 5: 34-37.

4. Lindgren CJ, Garcia GG, Saal MI (1996) Bank soundness and macroeconomic policy. International Monetary Fund.

5. Williams HT (2011) Determinants of capital adequacy in the Banking SubSector of the Nigeria Economy: Efficacy of Camels (a model specification with co-integration analysis). Int J Acad Res Bus Soc Sci 1: 233

6. Davidoff SM, Zaring D (2009) Regulation by deal: The government's response to the financial crisis. Admin L Rev 61: 463.

7. Coffee Jr JC (2009) What went wrong? An initial inquiry into the causes of the 2008 financial crisis. Journal of Corporate Law Studies 9: 1-22.

8. Chorafas D (2009) Financial boom and gloom: the credit and banking crisis of 2007-2009 and beyond. Springer.

9. Brewer lii E, Kaufman GG, Wall LD (2008) Bank capital ratios across countries: Why do they vary? Journal of Financial Services Research 34: 177-201.

10. Bordo MD (2008) An historical perspective on the crisis of 2007-2008. National Bureau of Economic Research.

11. Bieri DS (2008) The Basel process, financial stability, and the age of turbulence.

12. Bayne N (2008) Financial diplomacy and the credit crunch: The rise of central banks. J Int Aff, pp: 1-6.

13. Atik J (2010) Basel II: A post-crisis post mortem. Transnat'I L and Contemp Probs 19: 731

14. Al-Sabbagh NM, Magableh AH (2004) Determinants of capital adequacy ratio in Jordanian banks.

15. Moh'd Al-Tamimi KA, Obeidat SF (2013) Determinants of capital adequacy in commercial banks of Jordan an empirical study. International Journal of Academic research in Economics and management sciences 2: 44

16. Wong JC (2005) Determinants of the capital level of banks in Hong Kong. Hong Kong Monetary Authority Quarterly Bulletin, pp: 14-37.

17. Berrospide J, Edge R (2008) Linkages between the financial and real sectors: Some lessons from the subprime crisis. Federal Reserve Board Working Paper.

18. Koehn M, Santomero AM (1980) Regulation of bank capital and portfolio risk J Finance 35: 235-1244.

19. Madura J, Zarruk ER (1993) Market reaction to uniform capital adequacy guidelines in the banking industry. Journal of Economics and Finance 17: 59-72.

20. Yu MT (1996) Measuring fair capital adequacy holdings for banks: The case of Taiwan. Global Finance Journal 7: 239-252.

21. Sharpe WF (1964) Capital Asset Prices: A Theory of Market Equilibrium under Conditions of Risk. J Finance 19: 325-342.

22. Blose LE (2001) Information asymmetry, capital adequacy, and market reaction to loan loss provision announcements in the banking industry. Q Rev Econ Finance 41: 239-258.

23. Hassan MK, Bashir AH (2003) Determinants of Islamic banking profitability. In10th ERF annual conference, Morocco 7.

24. Choi G (2000) The macroeconomic implications of regulatory capital adequacy requirements for Korean banks. Economic Notes 29: 111-143.

25. Gosh D, Gosh S (2011) Management of non-performing assets in public secto banks: Evidence from India. International Conference on Management, pp: 750-760.

26. Harold S (1999) Capital adequacy: Will risk-based measurements help? Credit Union Executive Journal 39.

27. Meckhafi A (2004) Banks capital competence analysis-Yemeni banks-Yemen

28. Makhamreh M (2000) Corporate performance in Jordan: A study of the banking sector. The Arab Bank Review 2: 40-48.

29. Goddard JA, Molyneux P, Wilson JO (2004) Dynamics of growth and profitability in banking. J Money Credit Bank 36: 1069-1090.

30. Kosmidou K (2008) The determinants of banks' profits in Greece during the period of EU financial integration. Managerial Finance 34: 146-159.

31. Demirgüç-Kunt A, Huizinga $H$ (1999) Determinants of commercial bank interest margins and profitability: some international evidence. World Bank Econ Rev 13: $379-408$

32. Naceur SB (2003) The determinants of the Tunisian banking industry profitability: panel evidence. Universite Libre de Tunis working papers.

33. Pasiouras F, Kosmidou K, Gaganis C (2005) A pooled study of the internal and external determinants of Australian banks' profits and margins. Working Paper Financial Engineering Laboratory, Department of Production Engineering and Management, Technical University of Crete.

34. Valverde SC, Fernández FR (2007) The determinants of bank margins in European banking. J Bank Finance 31: 2043-2063.

35. Brock PL, Suarez LR (2000) Understanding the behavior of bank spreads in Latin America. J Dev Econ 63: 113-134.

36. Demirgüç-Kunt A, Laeven L, Levine $R$ (2003) The impact of bank regulations, concentration, and institutions on bank margins.

37. Saunders A, Schumacher $L(2000)$ The determinants of bank interest rate margins: an international study. J Int Money Finance 19: 813-832.

38. Olalekan A, Adeyinka S (2013) Capital adequacy and banks' profitability: An empirical evidence from Nigeria. Am Int J Contemp Res 3: 87-93

39. Odunga RM, Nyangweso PM, Carter DA, Mwarumba M (2013) Credit Risk, "Capital adequacy and operating efficiency of commercial banks in Kenya". International Journal of Business and Management Invention 2: 6-12.

40. Zerbe N (2001) Seeds of hope, seeds of despair: towards a political economy of the seed industry in southern Africa. Third World Quarterly 22: 657-673.

41. Said RM, Tumin MH (2011) Performance and financial ratios of commercial banks in Malaysia and China. International Review of Business Research Papers 7: 157-169.

42. Granger CW, Newbold P (1974) Spurious regressions in econometrics. J Econom 2: 111-120.

43. Wong J, Choi KF, Fong TP (2008) Determinants of the capital level of banks in Hong Kong. InThe Banking Sector in Hong Kong 2008 (pp. 159-190). Palgrave Macmillan, London.

44. Bokhari IH, Ali SM, Sultan K (2012) Determinants of capital adequacy ratio in banking Sector: An Empirical analysis from Pakistan.

45. Reynolds PD, Hay M, Bygrave WD, Camp SM, Autio E (2000) Global entrepreneurship monitor: 2000 executive report.

46. Marcus AJ (1983) The bank capital decision: A time series-cross section analysis. J Finance 38: 1217-1232.

47. Shome DK, Smith SD, Heggestad AA (1986) Capital adequacy and the valuation of large commercial banking organizations. Journal of Financial Research 9: 331-341.

48. Khraiwesh H, Al-Zobi K, Al-Abbadi M (2004) Factors affecting banking 
Citation: Abba GO, Okwa E, Soje B, Aikpitanyi LN (2018) Determinants of Capital Adequacy Ratio of Deposit Money Banks in Nigeria. J Account Mark 7: 271. doi: 10.4172/2168-9601.1000271

security: A Fidd study, Journal of King Abdel Aziz University, Economics and Management 18: 59-77.

49. Karels GV, Prakash AJ, Roussakis E (1989) The relationship between bank capital adequacy and market measures of risk. ¡ Bus Finance Account 16: 663-673

50. Mpuga P (2002) The 1998-99 banking crisis in Uganda: What was the role of the new capital requirements? Journal of Financial Regulation and Compliance 10: $224-242$

51. Kleff V, Weber M (2003) How do banks determine capital? Empirical evidence for Germany. Ger Econ Rev 9: 354-372.
52. Staikouras CH, Wood G (2003) The determinants of bank profitability in Europe Paper Presented at the European Applied Business Research Conference, Venice, Italy.

53. Abreu M, Mendes V (2001) Do macro-financial variables matter for European bank margins and profitability. Do macro-financial variables matter for European bank margins and profitability.

54. Pasiouras F, Kosmidou K (2007) Factors influencing the profitability of domestic and foreign commercial banks in the European Union. Research in International Business and Finance 21: 222-237. 